\title{
Effects of Starting Compositions and Operating Conditions on Synthesis of ZSM-5 from Kanuma Pumice, and the Properties of Catalysts in Alkylation of Tolvene with Methanol
}

\author{
Yuukei TAKASAKI*, Noboru IshiZaWA ${ }^{\dagger 1)}$, Yasuki NAMIKI ${ }^{\dagger 2}$ \\ Akira Yoshida ${ }^{\dagger 3)}$, and Takemi ShibuYa \\ Department of Applied Chemistry, Faculty of Engineering, Utsunomiya University, \\ Ishii-(ho, Utsunomiya 321 \\ 11) Present address: Tokyo Denryoku Co., Ltd., Tomioka-cho, \\ Futaba-gun, Fukushima 979-11 \\ 12) Present address: Shinnihon Seitetsu Co., Ltd., \\ Tokai-cho, Tokai-shi, Aichi 476 \\ 13) Present address: Toyota Jidohsya Co., I.td., \\ Toyota-cho, Toyota-shi, Aichi 471
}

(Received July 16, 1987)

\begin{abstract}
Kanuma pumice admixed with silicon dioxide was subjected to hydrothermal synthesis in a $\mathrm{NaOH}$ medium. Conditions for ZSM-5 zeolite synthesis without addition of any organic reagent as a template were examined. Furthermore, the catalytic properties of ZSM-5 from Kanuma pumice in the alkylation of toluene with methanol were compared with those of ZSM- 5 prepared from tetra- $n$-propyl ammonium. It was found that ZSM-5 from Kanuma pumice could also be used.
\end{abstract}

\section{Introduction}

Not only some soils, but also some clays contain humic substances formed by continuous decomposition of remains of animals or plants, and by reaction with soil or with clay. When weathered pumice from Kanuma, so called 'Kanuma-tsuchi' or 'Kohshitsu-do', which abounds in allophane of mineral clay, is used as a starting material for hydrothermal synthesis of zeolite, ZSM-5 zeolite can be synthesized without addition of any organic reagent as a template ${ }^{1)}$. It was found that this was due to the synergistic effect of the colloidal properties and humic substances of Kanuma pumice. To ascertain how the synthesis proceeds when the starting composition other than the compositions shown in the preceding paper $^{1)}$ is used, the authors investigated how the zeolite ZSM-5 synthesis depended on the concentrations of $\mathrm{NaOH}, \mathrm{SiO}_{2}, \mathrm{Al}_{2} \mathrm{O}_{3}$, and $\mathrm{H}_{2} \mathrm{O}$ in the starting material and on the operating conditions such as stirring, reaction temperature, and time for zeolitization. The authors further examined the effect of the synthesized ZSM-5 zeolite used as a catalyst in the alkylation of toluene with methanol by comparing it with that of ZSM-5 prepared with tetra- $n$-propylammonium iodide according to the Mobil's method 2 .

* To whom correspondence should be addressed.

\section{Experimental}

Materials, synthetic and product identification methods used are the same as those in the preceding paper ${ }^{1)}$. The starting molar composition (1) was $\mathrm{Na}_{2} \mathrm{O}: 5.0, \mathrm{SiO}_{2}: 41.0, \mathrm{Al}_{2} \mathrm{O}_{3}$ : 1.0, $\mathrm{H}_{2} \mathrm{O}$ : 940. The amounts of Kanuma pumice (wet), silicon dioxide, sodium hydroxide, and water used were $0.6460 \mathrm{~g}$ (0.2535 g-dry), $2.3400 \mathrm{~g}, 0.4089 \mathrm{~g}$ and $14.5667 \mathrm{~g}$, respectively. Starting composition (2) was $\mathrm{Na}_{2} \mathrm{O}: 3.5, \mathrm{Q}_{2} \mathrm{O}: 1.5, \mathrm{SiO}_{2}: 41.0, \mathrm{Al}_{2} \mathrm{O}_{3}: 1.0$, $\mathrm{H}_{2} \mathrm{O}: 940$ where $Q$ represented tetra- $n$-propylammonium ion (TPA). The synthesis of zeolites was hydrothermally carried out in a tubular autoclave (SUS 316) of 24-m $l$ with axial stirring of an amplitude of $10 \mathrm{~cm}$ per second. Amounts of uncalcined products (Na-ZSM-5) synthesized from starting compositions (1) and (2) by this "amplitude" method at $175^{\circ} \mathrm{C}$ for 24 hours were 0.5609 and $0.5856 \mathrm{~g}$-dry per $1 \mathrm{~g}$-solid in the starting composition, respectively. The products were designated as P-NaZSM5-AM and TPA-NaZSM5AM, respectively. Circumferential stirring was further examined in the autoclave placed in a rotating electric furnace to increase the stirring effect. ZSM-5 synthesized from the starting composition (1) by the "rotating" method (200 rpm) at $175^{\circ} \mathrm{C}$ for 24 hours was designated as P-NaZSM5-RM. The same conditions of measurements for powder XRD reported previously were used for comparison. 
The catalytic properties of the synthesized zeolites, including $\mathrm{Na}$ or $\mathrm{H}$ type of P-ZSM5-AM, TPA-ZSM5-AM, and P-ZSM5-RM, were examined with respect to the acidity and distribution of their acid strengths, and alkylation of toluene with methanol. The acidity and distribution of their acid strengths were measured by temperatureprogrammed desorption (TPD) of $\mathrm{NH}_{3}$ in the following manner: (1) $0.2 \mathrm{~g}$ of a sample was placed in a vessel; (2) pretreated in vacuo at $420^{\circ} \mathrm{C}$ for 1 hour; (3) $\mathrm{NH}_{3}$ was adsorbed at ambient temperature and the system was evacuated; (4) the bed temperature was increased at a rate of $10^{\circ} \mathrm{C} / \mathrm{min}$ in a $60 \mathrm{ml} / \mathrm{min} \mathrm{He}$ stream; (5) the desorbed $\mathrm{NH}_{3}$ was detected with a TC cell. The alkylation was carried out at $425^{\circ} \mathrm{C}$ by a pulse method (see blow) and $\mathrm{He}\left(20 \mathrm{~m} l \mathrm{~min}^{-1}\right)$ as a carrier gas, and the products were analyzed by gas chromatography. $20 \mathrm{mg}$ of the catalyst placed in a microreactor was pretreated in a $20 \mathrm{ml} \mathrm{min}{ }^{-1} \mathrm{He}$ stream at $430^{\circ} \mathrm{C}$ for 2 hours, and $0.7 \mu \mathrm{l}$ of a pulse of a mixture of equal volumes of toluene and methanol was injected into the microreactor.

\section{Results and Discussion}

\subsection{Influence of Reaction Temperature and Water Content on ZSM-5 Synthesis from Kanuma Pumice}

The water content in starting composition (1) was about 95 mole\%. The peak intensity $(2 \theta=$ $\left.23.0^{\circ}\right)$ in powder XRD patterns of the products from this composition ( 1 ) at $175^{\circ} \mathrm{C}$ changed with reaction time as shown in Fig. 1. The crystallinity of ZSM-5 reached a maximum after about 24 hours of reaction; it then slowly decreased with time to the intensity of about 70 (A.U.). At the same time, mordenite and $\alpha$-quartz were crystallized. When the reaction temperature was raised to $190^{\circ} \mathrm{C}$, the transformation of the zeolite phase was more pronounced rapid. The crystallinity of ZSM-5 reached a peak after 36 hours, since mordenite and $\alpha$-quartz had already appeared after 24 hours because of the high temperature $\left(190^{\circ} \mathrm{C}\right)$ involved. Amounts of ZSM-5 and mordenite both decreased with increasing amount of $\alpha$-quartz, and they finally disappeared after 48 hours. This fact suggests that ZSM-5 appear first as a metastable form and then be successively transformed into mordenite and $\alpha$-quartz in a more stable phase. When the reaction temperature was lowered to $150^{\circ} \mathrm{C}$, the induction period was prolonged from 6 hours to 48 hours, and the crystallinity of ZSM-5 ultimately reached the intensity of 100 after 72 hours. Mordenite and $\alpha$-quartz did not appear at this temperature.

The results obtained by changing the water

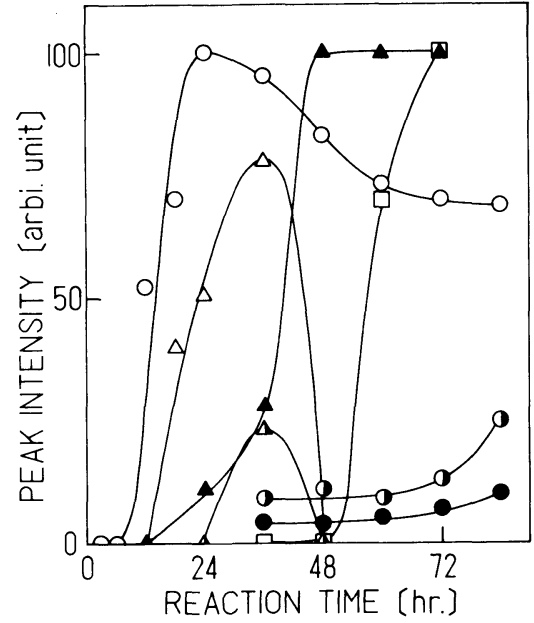

Fig. I Changes in Characteristic Peaks in XRD of Products at Varied Reaction Temperatures with Time

Reaction conditions: water content of $95 \mathrm{~mol} \%$

\begin{tabular}{|c|c|c|c|}
\hline key & temperature & products & peak $2 \theta$ \\
\hline $\begin{array}{l}\Delta \\
\Delta\end{array}$ & $190^{\circ} \mathrm{C}$ & $\begin{array}{c}\text { ZSM-5 } \\
\text { mordenite } \\
\alpha \text {-quartz }\end{array}$ & \multirow[t]{3}{*}{$\begin{array}{r}23.0^{\circ} \\
6.5^{\circ} \\
20.8^{\circ}\end{array}$} \\
\hline 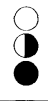 & $170^{\circ} \mathrm{C}$ & $\begin{array}{c}\mathrm{ZSM}-5 \\
\text { mordenite } \\
\alpha \text {-quartz }\end{array}$ & \\
\hline$\square$ & $150^{\circ} \mathrm{C}$ & ZSM-5 & \\
\hline
\end{tabular}

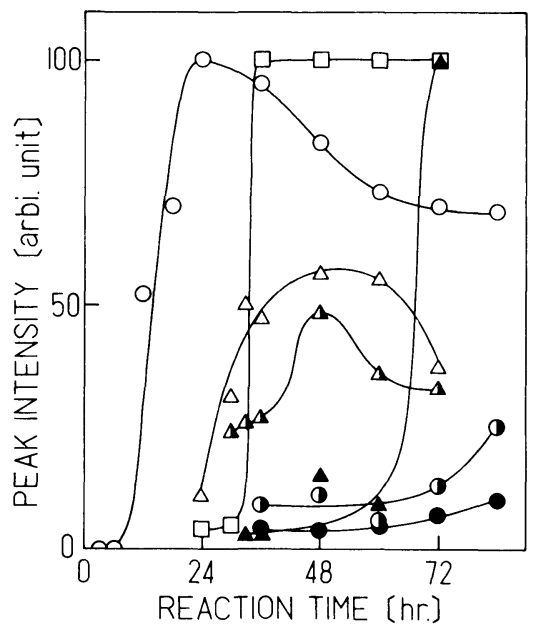

Fig. 2 Changes in Characteristic Peaks in XRD of Products under Varied Water Contents with Time

Reaction conditions: reaction temperature of $175^{\circ} \mathrm{C}$

\begin{tabular}{|c|c|c|c|}
\hline key & water content & products & peak $2 \theta$ \\
\hline $\begin{array}{l}\Delta \\
\Delta\end{array}$ & $93 \%$ & $\begin{array}{c}\text { ZSM-5 } \\
\text { mordenite } \\
\alpha \text {-quartz }\end{array}$ & \multirow[t]{3}{*}{$\begin{array}{r}23.0^{\circ} \\
6.5^{\circ} \\
20.8^{\circ}\end{array}$} \\
\hline 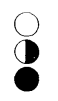 & $95 \%$ & $\begin{array}{c}\mathrm{ZSM}-5 \\
\text { mordenite } \\
\alpha \text {-quartz }\end{array}$ & \\
\hline$\square$ & $98 \%$ & ZSM-5 & \\
\hline
\end{tabular}


content in the starting composition at $175^{\circ} \mathrm{C}$ are shown in Fig. 2. After 24 hours of reaction, the amounts of uncalcined products synthesized with water contents of 93,95 , and $98 \%$ were 0.5346 , 0.5609 , and $0.504 \mathrm{lg}$-dry per $\mathrm{l} \mathrm{g}$-solid in the starting composition, respectively. When the water content was increased from 95 to $98 \%$, the induction period increased from 6 hours became to about 18 hours owing to the decrease in the raw material concentration. However, the XRD peak intensity of ZSM-5 reached 100 after 36 hours, and this state was maintained for 60 hours. Neither mordenite nor $\alpha$-quartz was formed. When the water content was decreased from 95 to $93 \%$, stirring could not be carried out thoroughly due to the resulting higher concentration, that is, an increase in the solid content of the starting material. Consequently, the induction period was longer than was expected; and ZSM-5 was present together with mordenite and $\alpha$-quartz, and its intensity was as low as 60. $\alpha$-Quartz became predominant after 72 hours. These results indicated that ZSM-5 was selectively synthesized under mild reaction conditions, but transformed into mordenite and $\alpha$-quartz under more severe conditions. It was found that ZSM-5 was selectively synthesized by reacting with $95 \%$ water content at $175^{\circ} \mathrm{C}$ for 24 hours.

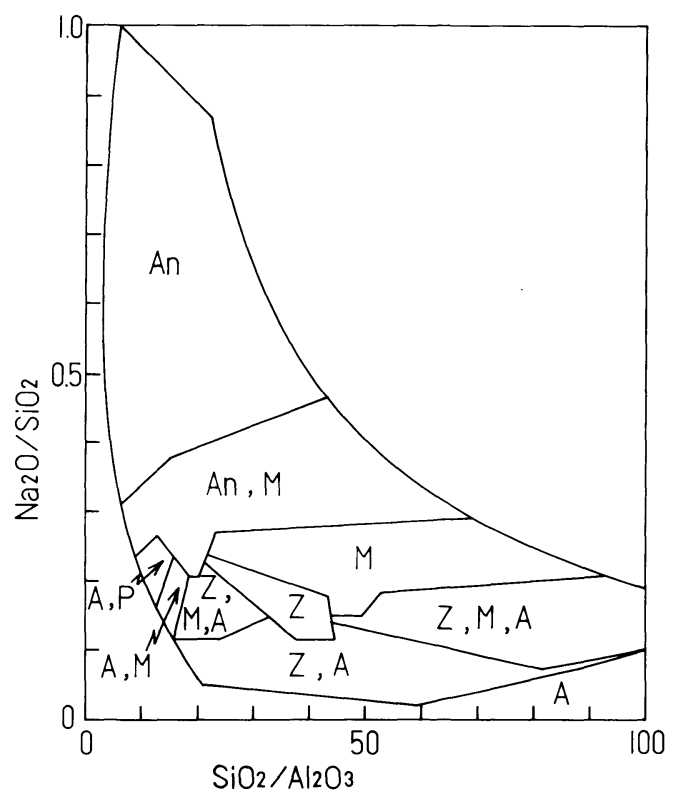

Fig. 3 Isothermal Phase Diagram of the Products of Zeolite Formed from Kanuma Pumice

Reaction conditions: water content of $95 \%$, temperature of $175^{\circ} \mathrm{C}$, time of 24 hours Key: An: analcime, M: mordenite, Z: ZSM-5, P: zeolite $\mathrm{P}, \mathrm{A}$ : amorphous, $\alpha$ : $\alpha$-quartz ( $\alpha$-quartz occurred in the dotted line region in Fig. 5)

\subsection{Influences of Starting Composition on ZSM- 5 Synthesis from Kanuma Pumice}

It is known that to synthesize a metastable phase depends greatly upon the starting composition. Effects of molar ratios of $\mathrm{SiO}_{2} / \mathrm{Al}_{2} \mathrm{O}_{3}$ and $\mathrm{Na}_{2} \mathrm{O} / \mathrm{SiO}_{2}$ on the synthesis of zeolites were examined. The synthesis was carried out with water content $95 \%$ at $175^{\circ} \mathrm{C}$ for 24 hours. The product phase diagram is shown in Fig. 3. This is an overall result of about 70 starting compositions with varying $\mathrm{SiO}_{2} / \mathrm{Al}_{2} \mathrm{O}_{3}$ ratios from 5 to 100 and $\mathrm{Na}_{2} \mathrm{O} / \mathrm{SiO}_{2}$ ratios varying from nearly 0 to 1 . The metastable phases besides ZSM-5 in the diagram are three, i.e. those for analcime, mordenite, and zeolite $P$. These phases were identified with those described in the ASTM cards. The blank on the upper right side in the diagram is the region where solid products could not adequately be obtained in an autoclave of 24- $\mathrm{m} l$ capacity so as to conduct X-ray diffraction. A tendency for the metastable phases to be transformed successively into ZSM-5, mordenite, and analcime by increasing the alkali content at a constant ratio of $\mathrm{SiO}_{2} / \mathrm{Al}_{2} \mathrm{O}_{3}$ was observed; also a tendency for substantially the same metastable phase to be synthesized even if the ratio of $\mathrm{SiO}_{2} / \mathrm{Al}_{2} \mathrm{O}_{3}$ was varied at nearly a constant ratio of $\mathrm{Na}_{2} \mathrm{O} / \mathrm{SiO}_{2}$ was observed. From these facts it can be seen that the synthesized metastable phase depends largely on the ratio of $\mathrm{Na}_{2} \mathrm{O} / \mathrm{SiO}_{2}$ of the starting composition rather than on the ratio of $\mathrm{SiO}_{2} / \mathrm{Al}_{2} \mathrm{O}_{3}$.

$\mathrm{Next}$, the water content was increased from 95 to $98 \%$, and the results depicted in a phase diagram are shown in Fig. 4. The diagram is on the whole extended toward the higher $\mathrm{SiO}_{2} / \mathrm{Al}_{2} \mathrm{O}_{3}$ value than is in Fig. 3. The region where ZSM-5 was synthesized in a single phase has a higher ratio of $\mathrm{SiO}_{2} / \mathrm{Al}_{2} \mathrm{O}_{3}$ by $35-80$ and a wider range of $\mathrm{Na}_{2} \mathrm{O} / \mathrm{SiO}_{2}$ ratios. This seems to be attributable to the fact that the metastable phase of $\mathrm{ZSM}-5$ is present even in the region of higher $\mathrm{SiO}_{2}$ /

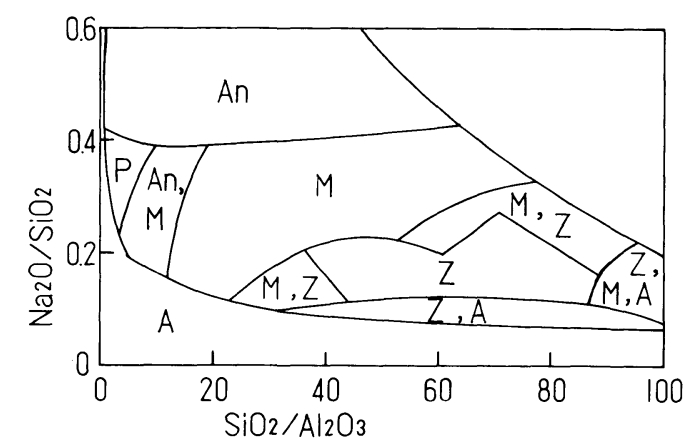

Fig. 4 Isothermal Phase Diagram of the Products Reaction conditions: water content of $98 \%$, temperature of $175^{\circ} \mathrm{C}$, time of 24 hours 
$\mathrm{Al}_{2} \mathrm{O}_{3}$ ratios, because the concentration of the starting composition is low; thus, the transformation proceeds slowly as seen in the foregoing section.

On the other hand, a diagram obtained by raising the reaction temperature from 175 to $190^{\circ} \mathrm{C}$ using the same water content and reaction time as those in Fig. 3 is shown in Fig. 5. A similar tendency to that shown in Fig. 4 is seen in Fig. 5. The phase containing a very small amount of $\alpha$-quartz is present over a wide region as can be expected from Fig. 1. From the viewpoint of

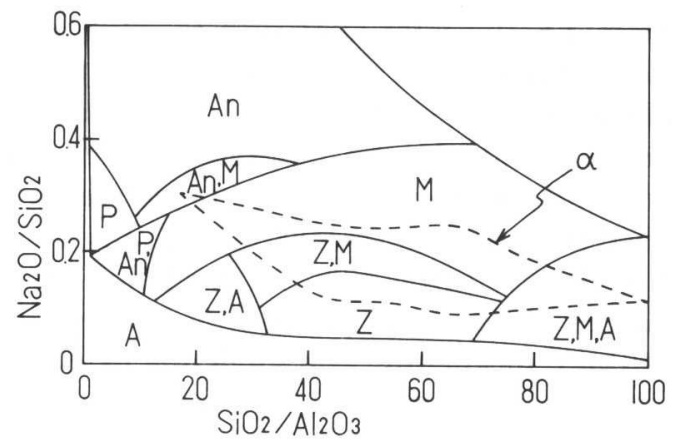

Fig. 5 Isothermal Phase Diagram of Products

Reaction conditions: water content of $95 \%$, temperature of $190^{\circ} \mathrm{C}$, time of 24 hours

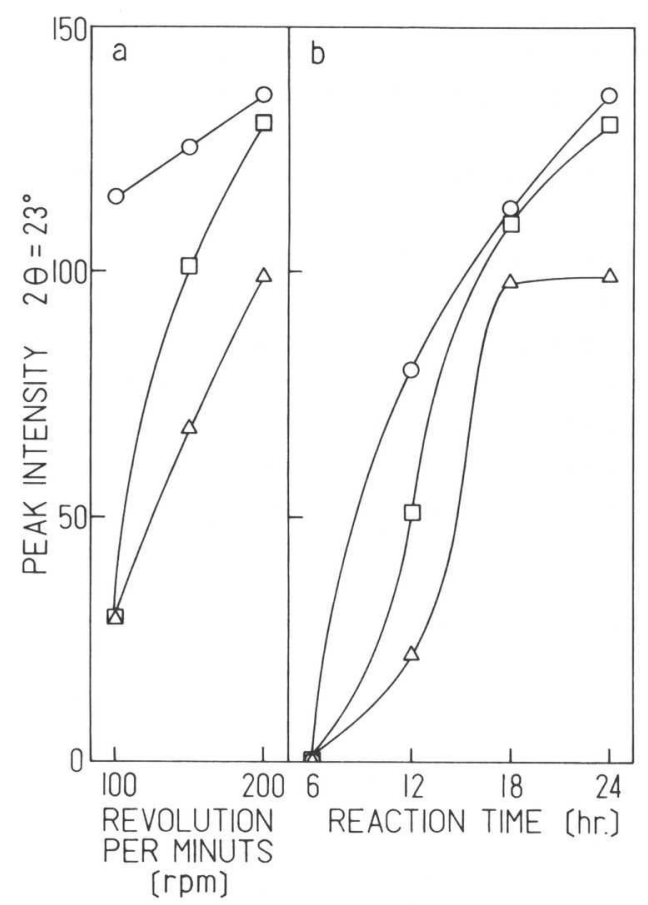

Fig. 6 Changes in Primary Peak $\left(2 \theta=23.0^{\circ}\right)$ in XRD of ZSM-5 Synthesized with Varied Revolution per Minute as a Function of the Speed of Revolution (a) and the Reaction Time (b)

Reaction conditions: temperature of $175^{\circ} \mathrm{C}$ water content $\square: 93 \%, \bigcirc: 95 \%, \triangle: 98 \%$ a: after 24 hours, b: at $200 \mathrm{rpm}$ transformation of the metastable phase, it is quite strange that ZSM-5 is present together with $\alpha$ quartz. This seems to be ascribable to the faster transformation of mordenite to $\alpha$-quartz than that of ZSM-5 to mordenite when the reaction temperature is raised, rather than to the accelerated transformation to the stable phase. This is also supported by the fact that the single phase of ZSM-5 can be synthesized at low ratios of $\mathrm{Na}_{2} \mathrm{O} / \mathrm{SiO}_{2}$ under more gentle reaction conditions. Kulkarni et al ${ }^{3}$ ) has also showed that ZSM-5 can be present together with $\alpha$-quartz, depending upon synthetic conditions, even when tetrapropylammonium or triethyl- $n$-propylammonium bromide is used as an organic reagent.

\subsection{Influence of Stirring on ZSM-5 Synthesis from Kanuma Pumice}

Results of the effects of stirring on ZSM-5 synthesis from starting compositions of the following water contents; 93,95 , and $98 \%$ at $175^{\circ} \mathrm{C}$ for 24 hours are shown in Fig. 6a. Amounts of uncalcined products synthesized at $200 \mathrm{rpm}$ from the above water contents were, respectively, $0.563 \mathrm{l}, 0.5629$, and $0.5730 \mathrm{~g}$-dry per $1 \mathrm{~g}$-solid in the starting composition. Changes in crystallinity with time at $200 \mathrm{rpm}$ are shown in Fig. 6b. The crystallinity of ZSM-5 increased with increasing rpm, but the starting materials were thrown onto walls of the autoclave by centrifugal force when rpm exceeded 200. The crystallinity of ZSM-5 then decreased by drop in stirring effect. The

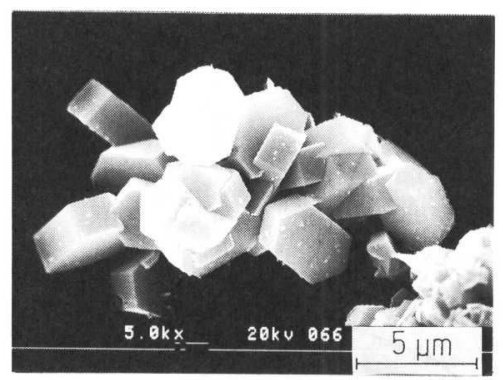

(a)

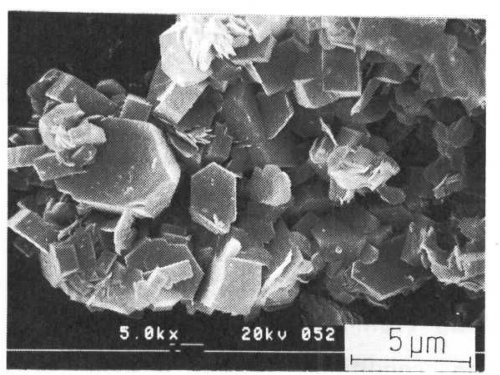

(b)

Fig. 7 SEM of ZSM-5 Formed from Kanuma Pumice at $200 \mathrm{rpm}$, (a) Water Content of $95 \%$, (b) $93 \%$ 
synthesis with $98 \%$ water content required 36 hours until the peak intensity reached 100 as shown in Fig. 2, but 24 hours were sufficient at $200 \mathrm{rpm}$. The synthesis with $93 \%$ water content was improved by stirring effect as shown in Fig. 2, though the presence of large quantities of solid matters prevented thorough stirring. The peak intensity exceeded 100 at $150 \mathrm{rpm}$ or more. The peak intensity with $95 \%$ water content exceeded 100 at less than $100 \mathrm{rpm}$. These facts were confirmed as shown in Fig. 6b that even though there was an induction period of 6 hours in all cases; 18 hours was adequate for crystallization. SEM of ZSM-5 synthesized with the water contents of 95 and $93 \%$ at $200 \mathrm{rpm}$ exhibited excellent crystallization as shown in Figs. $\mathbf{7 a}$ and $\mathbf{7 b}$, respectively. It was found in these SEMs that growth of the crystals proceeded up to a secondary particle.

\subsection{Catalytic Properties of Synthesized Zeolites}

TPD spectra obtained were characterized by three desorption peaks (l-, m-, and h-peaks at low, moderate, and high temperatures, respectively) on the $\mathrm{H}$ type of every zeolite; and by two peaks (l-and m-peaks) on the $\mathrm{Na}$ type, as shown in Fig. 8. The l-peak is ascribable to very weakly or physically adsorbed ammonia on zeolites, and if does not depend on the catalyst properties, but rather on the experimental conditions ${ }^{4)}$. Thus, the acidity is defined as a total of $\mathrm{m}$ - and h-peak areas. Acid strengths can be estimated from the peak maximum temperatures of $\mathrm{m}$ - and/or $\mathrm{h}$ peaks. A comparison of these temperatures resulted in the following sequences for the acid strengths of $\mathrm{H}$ - and $\mathrm{Na}$-zeolites, respectively:

$$
\begin{gathered}
\text { P-HZSM5-RM = TPA-HZSM5-AM } \\
>\text { P-HZSM5-AM } \\
\text { P-NaZSM5-RM }>\text { P-NaZSM5-AM } \\
>\text { TPA-NaZSM5-AM }
\end{gathered}
$$

While a comparison of these areas gave the following sequence for the acidity of each type:

$$
\begin{gathered}
\text { P-ZSM5-RM }>\text { TPA-ZSM5-AM } \\
>\text { P-ZSM5-AM }
\end{gathered}
$$

The weak acidity of P-HZSM5-AM can be attributed to the fact that ion exchange had not sufficiently been done for the zeolite from impuritycontaining pumice.

Results of the alkylation of toluene with

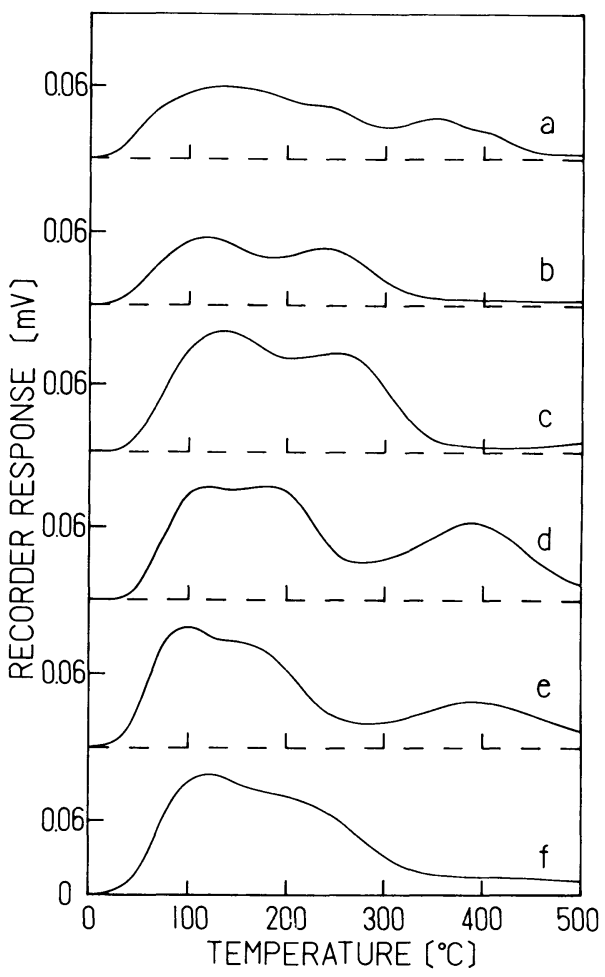

Fig. 8 TPD of $\mathrm{NH}_{3}$ on $\mathrm{ZSM}-5$
(a) P-HZSM5-AM,
(b) P-NaZSM5-AM,

\begin{tabular}{|c|c|c|c|c|c|c|c|}
\hline \multirow{3}{*}{\multicolumn{2}{|c|}{ Catalyst }} & \multicolumn{4}{|c|}{ Kanuma pumice } & \multirow{2}{*}{\multicolumn{2}{|c|}{$\begin{array}{l}\text { Mobil's method } \\
\text { Amplitude method }\end{array}$}} \\
\hline & & \multicolumn{2}{|c|}{ Amplitude method } & \multicolumn{2}{|c|}{ 200-rpm Rotating method } & & \\
\hline & & P-NaZSM5-AM & P-HZSM5-AM & P-NaZSM5-RM & P-HZSM5-RM & $\begin{array}{c}\text { TPA- }^{-} \\
\text {NaZSM5-AM }\end{array}$ & $\begin{array}{c}\text { TPA- } \\
\text { HZSM5-AM }\end{array}$ \\
\hline \multicolumn{2}{|c|}{$\begin{array}{l}\text { Conversion of } \\
\text { toluene }(\%)\end{array}$} & 32.8 & 50.8 & 35.9 & 49.1 & 63.3 & 46.9 \\
\hline \multicolumn{2}{|c|}{$\begin{array}{c}\text { Selectivity to } \\
p-/ m-/ o \text {-xylene }(\%)\end{array}$} & $100 / 0 / 0$ & $33 / 47 / 20$ & $70 / 13 / 18$ & $39 / 46 / 14$ & $39 / 46 / 14$ & $27 / 65 / 8$ \\
\hline $\begin{array}{l}\text { Yield of products } \\
\text { based on toluene } \\
\text { used }(\%) \\
\text { Others* }\end{array}$ & $\begin{array}{l}p \text {-xylene } \\
m \text {-xylene } \\
o \text {-xylene } \\
\text { benzene }\end{array}$ & $\begin{array}{l}22.3 \\
0 \\
0 \\
0 \\
77.7\end{array}$ & $\begin{array}{r}16.4 \\
23.3 \\
9.8 \\
2.2 \\
48.3\end{array}$ & $\begin{array}{r}32.7 \\
5.9 \\
8.4 \\
0 \\
53.0\end{array}$ & $\begin{array}{r}16.2 \\
19.1 \\
5.8 \\
2.8 \\
56.1\end{array}$ & $\begin{array}{r}20.7 \\
24.5 \\
7.5 \\
3.4 \\
43.9\end{array}$ & $\begin{array}{r}20.1 \\
48.4 \\
5.6 \\
7.5 \\
18.4\end{array}$ \\
\hline
\end{tabular}
(c) P-NaZSM5-RM,
(d) P-HZSM5-RM,
(e) TPA-HZSM5-AM, (f) TPA-NaZSM5-AM
Nomenclature is shown in the text.

Table 1 Comparison of Alkylation of Toluene with Methanol

Experimental conditions are shown in the text.

Others ${ }^{*}$ contained ethylbenzene, $p$-ethyltoluene, $m$-ethyltoluene and trimethylbenzene. 
methanol over different zeolites are given in Table 1. In spite of about one-half acidity of TPAHZSM5-AM on m- and h-peaks, P-HZSM5-AM gave nearly the same conversion of toluene and also nealy the same yield of $p$-xylene as did TPAHZSM5-AM. P-HZSM5-RM having strong acidity for $\mathrm{m}$ - and h-peaks also showed almost the same values as P-HZSM5-AM. These results imply that strong acidity for $\mathrm{m}$ - and h-peaks is not necessarily important to this reaction. - Despite almost the same conversion of toluene, P-HZSM5-RM and PHZSM5-AM gave smaller yields of xylene isomers, especially of $m$-xylene than TPA-HZSM5-AM. It is generally known that the basic sites of zeolites are active for alkylation of the methyl group of toluene ${ }^{5), 6)}$. These facts suggest that the yield of ethylbenzene for either P-HZSM5-RM or PHZSM5-AM be larger than that for TPA-HZSM5AM. On the other hand, there was a significant difference among the three types of Na-ZSM-5. P-NaZSM5-AM gave half the conversion that TPA-NaZSM5-AM did, but produced only $p$ xylene, indicating its selectivity to $p$-xylene to be $100 \%$. The conversion over P-NaZSM5-RM was nearly equal to that over P-NaZSM5-AM. The selectivity to $p$-xylene for the former catalyst was between that for the latter and that for TPAZSM5-AM.

As described above, it was confirmed that the ZSM-5 zeolites synthesized from Kanuma pumice was as effective as those prepared by known methods, including the Mobil's method, for the catalytic alkylation of toluene with methanol to xylene and ethylbenzene, and the zeolites even showed higher selectivity to $p$-xylene than to other xylene isomers. The selectivity depended on the conditions of synthesis of the zeolites which could be also used for other catalytic reactions.

\section{Conclusions}

When Kanuma pumice was used in the starting composition (1), ZSM-5 could be synthesized owing to the effect of humic substances, but sometimes it could not depending upon the operating conditions. It was found that ZSM-5 could selectively and effectively be synthesized under mild reaction conditions; i.e., at $175^{\circ} \mathrm{C}$ and for 24 hours; however, it was transformed into mordenite and $\alpha$-quartz under more severe conditions. It was also found that the phases of the products obtained depended distinctly on the starting composition; i.e., water content, the ratios of $\mathrm{SiO}_{2} / \mathrm{Al}_{2} \mathrm{O}_{3}, \mathrm{Na}_{2} \mathrm{O} / \mathrm{SiO}_{2}$, etc.. Typical results are summerized in the phase diagrams that show relationships between the starting composition and the product. The diagrams clearly show that whether the metastable phase or ZSM-5 is selectively synthesized or not depends largely on the ratio of $\mathrm{Na} 2 \mathrm{O} / \mathrm{SiO}_{2}$ rather than on the ratio of $\mathrm{SiO}_{2} / \mathrm{Al}_{2} \mathrm{O}_{3}$ in the starting composition. With increasing water content in the starting composition from 95 to $98 \%$, or with increasing reaction temperature from 175 to $190^{\circ} \mathrm{C}, \mathrm{ZSM}-5$ could be synthesized up to a high ratio of $\mathrm{SiO}_{2} / \mathrm{Al}_{2} \mathrm{O}_{3}$, i.e. from 45 up to 90 or 75 . The effect of stirring could be increased by the rotating method in place of the amplitude method, and the crystals of ZSM-5 could be grown to secondary particles. A comparison of acid strengths of $\mathrm{H}$ and $\mathrm{Na}$ types of ZSM-5 gave rise to sequences (1) and (2), respectively, and a comparison of acidities of each type gave sequence (3). The reactivity of toluene with methanol was not significantly different among the H-ZSM-5's synthesized according to different methods. The conversion of toluene over $P$ NaZSM5-AM was about half of that over TPANaZSM5-AM, but the former could produce only p-xylene. P-NaZSM5-RM showed the same level of conversion as that of the former and a lower selectivity to $p$-xylene. It was found that ZSM-5 zeolites synthesized from Kanuma pumice are as effective for alkylation of toluene with methanol as those prepared by conventional or known methods.

\section{References}

1) Takasaki, Y., Ishizawa, N., Namiki, Y., Shibuya, T., Hasegawa, K., Sekiyu Gakkaishi, 31, (4), 314 (1988).

2) Argauer, R. J., Landolt, R. G., U.S. 3,702,886 (1972).

3) Kulkarni, S. B., Shiralkar, V. P., Kotasthane, A. N., Borade, R. B., Ratnasamy, P., Zeolites, 2, 313 (9182).

4) Niwa, M., Iwamoto, M., Segawa, K., Bull. Chem. Soc. Jpn., 59, 3735 (1986).

5) Bhat, S. G. T., J. Catal., 75, 196 (1982).

6) Yashima, T., Sato, K., Hayasaka, T., Hara, N., J. Catal., 26, 303 (1972). 
要 旨

鹿沼軽石からの ZSM-5 合成における出発組成と操作条件の効果および生成 ZSM-5 の触媒特性

高菩 裕圭, 石沢 昇 ${ }^{+1)}$, 並木 泰樹 ${ }^{+2)}$, 吉田 顕彰 ${ }^{\dagger 3}$, 渋谷 剛美

宇都宮大学工学部工業化学科, 321 宇都宮市石井町 2753
†1)現在: 東京電力福島発電所, 979-11 福島県双葉郡富岡町
${ }^{+2)}$ 現在 : 新日本製鐵名古屋製鉄所, 476 東海市東海町
${ }^{+3)}$ 現在 : トヨタ自動車, 471 豊田市豊田町

前報1)では，一組の出発組成について，鹿沼軽石を用いた ZSM-5 ゼオライト (P-NaZSM-5) の合成を検討した。続いて 本報では，触媒調製の観点から， $\mathrm{Na}_{2} \mathrm{O}, \mathrm{SiO}_{2}, \mathrm{Al}_{2} \mathrm{O}_{3}, \mathrm{H}_{2} \mathrm{O}$ な ど出発組成の濃度, および, 合成時の温度, 時間, かくはんな どの操作条件による ZSM-5 合成条件の变化を検討した。

鹿沼軽石などの原料, ゼオライト合成の方法, 生成ゼオライ トの同定法は, 前報と同じであった。出発組成( 1 )のモル組成 $\mathrm{Na}_{2} \mathrm{O}: 5.0, \mathrm{SiO}_{2}: 41.0, \mathrm{Al}_{2} \mathrm{O}_{3}: 1.0, \mathrm{H}_{2} \mathrm{O}: 940$ において, 反応 温度抢よび水分を変化させた時, 生成物の XRD における特性 ピークは，それぞれ Figs. 1, 2 のように，時間とともに変化し た。いずれの場合も, 誘導期間の後に ZSM-5 が出現し, 反応 の経過とともに，モルデナイト，さらに $\alpha$-石英へと準安定相 が推移していく傾向があった。

つぎに, $175^{\circ} \mathrm{C}, 24$ 時間, 水分 $95 \%$ の合成条件において, 出発組成中の $\mathrm{Na}_{2} \mathrm{O} / \mathrm{SiO}_{2}$ と $\mathrm{SiO}_{2} / \mathrm{Al}_{2} \mathrm{O}_{3}$ モル比に対する生成 物の相図を Fig. 3 に示す。合成される準安定相は, 出発組成 の $\mathrm{SiO}_{2} / \mathrm{Al}_{2} \mathrm{O}_{3}$ 比よりも, $\mathrm{Na}_{2} \mathrm{O} / \mathrm{SiO}_{2}$ 比に依存することがわ かった。Fig. 3 の水分を $95 \%$ から $98 \%$ 一増加した時, 得ら れる生成物の相図を Fig. 4 に示す。ZSM-5 の得られる領域 が高 $\mathrm{SiO}_{2} / \mathrm{Al}_{2} \mathrm{O}_{3}$ 側へ移動した。また, Fig. 3 の反応温度を $175^{\circ} \mathrm{C}$ から $190^{\circ} \mathrm{C}$ 一上昇した時, 得られる生成物の相図を Fig. 5 に示す。ごく少量の $\alpha$-石英を共存する相が広範囲に存 在した。これは, ZSM-5 がモルデナイトへ推移する速度より も，モルデナイトが $\alpha$-石英へ推移する速度の方が大きいこと に起因していると思われる。

さらに, $175^{\circ} \mathrm{C}, 24$ 時間で，出発組成（1)において水分を 93
$\%, 95 \%, 98 \%$ として合成した ZSM-5 に対するかくはんの影 響を Fig. 6aに示す。また, 200 回転における結晶化の時間変 化を Fig. 6b に示す。回転数の増加とともに，また濃度（固 型物質）の増加とともに, ZSM-5 の結晶化度は増加した。か くはん効果を増加すると, 結晶化の時間を短縮できることがわ かった。Fig. 7 に 200 回転, 水分 $95 \%, 93 \%$ で合成した ZSM-5 の SEM を示す。

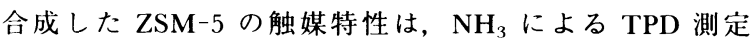
(Fig. 8) と, トルエンのメタノールによるアルキル化反応の 測定 (Table 1) によって調べた。使用したゼオライトは, 出 発組成 $(1)$ を振幅法（振幅 $10 \mathrm{~cm}, 60$ 回/秒) と回転法 $(200$ $\mathrm{rpm})$ で, $175^{\circ} \mathrm{C}, 24$ 時間で合成した ZSM-5（それぞれ P-ZSM5-AM, P-ZSM5-RM) の Na と H 型である。また, テ トラーn-プロピルアンモニゥム（TPA）塩を用いて合成したも の（TPA-ZSM5-AM）についても測定した。 H と Na 型の酸 強度を比較して，それぞれ序列（１），（2）を得た。酸性度につ いては, 両型とも序列 $(3)$ を得た。トルエンのメタノールに対 する反応性は, 各法の H 型において大きな差がなかったが, Na 型においては異なった。P-NaZSM5-AM は, トルエンの 転化率については TPA-NaZSM5-AM の半分であったが, $p^{-}$ キシレンのみを生成した。P-NaZSM5-RM は, TPANaZSM5-AM と同じ程度のトルエン転化率を示したが, $p^{-}$キ シレン選択率はむしろ低かった。鹿沼軽石から合成した ZSM-5 は, トルエンのアルキル化について, 既知法で調製し たものと同程度有効であった。

\section{Keywords}

Catalyst preparation, Grystallization, Pumice, Zeolite, ZSM-5 